\title{
Application of Cement Clinker as Ni-Catalyst Support for Glycerol Dry Reforming
}

\author{
Hua Chyn Lee, Kah Weng Siew, Jolius Gimbun, Chin Kui Cheng * \\ Faculty of Chemical \& Natural Resources Engineering, Universiti Malaysia Pahang, Lebuhraya \\ Tun Razak, 26300 Gambang Kuantan, Pahang, Malaysia
}

Received: 30th May 2013; Revised: 27th August 2013; Accepted: 11st September 2013

\begin{abstract}
The increase in biodiesel production inevitably yield plethora of glycerol. Therefore, glycerol has been touted as the most promising source for bio-syngas (mixture of $\mathrm{H}_{2}$ and $\mathrm{CO}$ ) production. Significantly, coking on nickel-based catalysts has been identified as a major deactivation factor in reforming technology. Indeed, coke-resistant catalyst development is essential to enhance syngas production. The current work develops cement clinker (comprised of $62.0 \%$ calcium oxide)-supported nickel catalyst (with metal loadings of 5,10 , 15 and $20 \mathrm{wt} \%)$ for glycerol dry reforming $\left(\mathrm{CO}_{2}\right)$. Physicochemical characterization of the catalysts was performed using XRD, XRF, BET, TGA and FESEM-EDS techniques. Subsequently, reaction studies were conducted in a $7-\mathrm{mm}$ ID fixed-bed stainless steel reactor at $1023 \mathrm{~K}$ with various $\mathrm{CO}_{2}$ partial pressures at constant weight-hourly space velocity (WHSV) of $7.2 \times 104 \mathrm{ml} \mathrm{g}_{\mathrm{cat}}{ }^{-1} \mathrm{~h}^{-1}$. Gas compositions were determined using Agilent 3000 micro-gas chromatography (GC) and Lancom III gas analyzer. Results obtained showed an increment of BET surface area up to 32 -fold with Ni loading which was corroborated by FESEM images. Syngas $\left(\mathrm{H}_{2}\right.$ and $\left.\mathrm{CO}\right)$ ratios of less than 2 were being produced at $1023 \mathrm{~K}$. A closer scrutiny to the transient profile revealed that the presence of $\mathrm{CO}_{2}$ higher or lower than CGR 1:1 promotes the Boudouard reaction. (C) 2013 BCREC UNDIP. All rights reserved
\end{abstract}

Keywords: Bio-syngas; cement clinker; glycerol; dry reforming

How to Cite: Lee, H.C., Siew, K.W., Cheng, C.K. (2013). Application of Cement Clinker as Ni-Catalyst Support for Glycerol Dry Reforming. Bulletin of Chemical Reaction Engineering \& Catalysis, 8 (2): 137-144.

(doi:10.9767/bcrec.8.2.5023.137-144)

Permalink/DOI: http://dx.doi.org/10.9767/bcrec.8.2.5023.137-144

\section{Introduction}

Post year 2008, in the aftermath of global energy crisis sparked by the sudden surge in the price of petroleum fuel, the search for renewable and sustainable energy source has become imperative. For countries with meager proven petroleum reserves such as Malaysia, a moratorium on petro-

* Corresponding Author.

E-mail: chinkui@ump.edu.my (C.K. Cheng)

Tel: +60-9-5492896, Fax: +60-9-5492889 leum oil production could spell a disaster to the economy; hence energy security in the context of leveraging on the country's biodiversity is clearly the only way out from the energy malaise. Significantly, syngas $\left(\mathrm{H}_{2}\right.$ and $\left.\mathrm{CO}\right)$ production from glycerol bio-waste ( $10 \mathrm{wt} \%$ of crude glycerol per $\mathrm{kg}$ of biodiesel from the transesterification process) has been touted as one of the most promising route in achieving sustainable energy requirement. Indeed, the $\mathrm{H}_{2}$ combustion value is $122 \mathrm{~kJ} \mathrm{~g}^{-1}$, which is 2.75-fold of hydrocarbon fuels [1]. In theory, 1 mole of glycerol can decompose to $3 \mathrm{~mol}$ of $\mathrm{CO}$ and $4 \mathrm{~mol}$ 
of $\mathrm{H}_{2}$ (cf. Equation (1)).

$$
\mathrm{C}_{3} \mathrm{H}_{8} \mathrm{O}_{3}(\mathrm{~g}) \leftrightarrow 3 \mathrm{CO}(\mathrm{g})+4 \mathrm{H}_{2}(\mathrm{~g})
$$

Production of syngas from glycerol steam reforming has been studied. However, it does not yield favourable $\mathrm{H}_{2}$ :CO ratio for Fisher-Tropsch (FT) synthesis. Besides, it also emits $\mathrm{CO}_{2}$ (cf. Equation (2)).

$$
\mathrm{C}_{3} \mathrm{H}_{8} \mathrm{O}_{3}(\mathrm{~g})+3 \mathrm{H}_{2} \mathrm{O}(\mathrm{g}) \leftrightarrow 3 \mathrm{CO}_{2}(\mathrm{~g})+7 \mathrm{H}_{2}(\mathrm{~g})
$$

In particular, glycerol dry reforming as shown in Equation (3) is a new area and no prior works have been published on it. Theoretical consideration alone indicates that it is more viable for syngas production intended for FT synthesis as well as utilizing the greenhouse gas, $\mathrm{CO}_{2}$. Wang et al. [2] from their thermodynamic analysis reported that glycerol dry reforming is able to produce 6.4 moles of syngas per mole of glycerol.

$$
\mathrm{C}_{3} \mathrm{H}_{8} \mathrm{O}_{3}(\mathrm{~g})+\mathrm{CO}_{2}(\mathrm{~g}) \leftrightarrow 4 \mathrm{CO}(\mathrm{g})+3 \mathrm{H}_{2}(\mathrm{~g})+\mathrm{H}_{2} \mathrm{O}(\mathrm{g})
$$

In reforming technologies, Ni catalyst has been widely used due to its availability and low costs compared to noble metals such as Rh, Pt and Pd [35]. Nonetheless, the main drawback associated with $\mathrm{Ni}$ is severe carbon deposition (coking). Significantly, coking onto the catalysts can be reduced by the addition of strong Lewis base oxide such as $\mathrm{CaO}$ [6-10] previously reported that cement clinker contains $63.28 \%$ and $63.17 \% \mathrm{CaO}$, respectively. Importantly, it is an abundant source from cement industry in Malaysia. Endowed by thermal stability, cement clinker hence offers great potential as suitable support for Ni catalyst.

The current work serves to characterize the synthesized cement clinker-supported nickel catalysts using spectroscopic analysis and also to investigate the activity of glycerol dry reforming over the cement clinker-supported $\mathrm{Ni}$ catalyst with the aims of producing syngas mixture suitable for FT synthesis and enhancing catalytic stability through carbon lay down reduction.

\section{Materials and Methods}

\subsection{Materials and Catalyst preparation}

Cement clinker (CC) was obtained from the $\mathrm{Pa}$ hang Cement Sdn. Bhd. after the cement kiln which undergone calcination at 1673 to $1723 \mathrm{~K}$. All the chemicals such as nickel (II) nitrate hexahydrate $\left(\mathrm{Ni}\left(\mathrm{NO}_{3}\right)_{2} \cdot 6 \mathrm{H}_{2} \mathrm{O}\right)$ and pure glycerol were analytical grade purchased from Sigma-Aldrich. Catalysts were prepared via wet-impregnation of $\mathrm{CC}$ with $5 \mathrm{wt} \%, 10 \mathrm{wt} \%, 15 \mathrm{wt} \%$ and $20 \mathrm{wt} \%$ nickel (Ni)-metal respectively using $\mathrm{Ni}\left(\mathrm{NO}_{3}\right)_{2} \cdot 6 \mathrm{H}_{2} \mathrm{O}$ solution prepared from $50 \mathrm{ml}$ ultrapure water (Milipore Elix 5-UV) as precursors. The slurry was then stirred for $3 \mathrm{~h}$ at room temperature before ovendried at $403 \mathrm{~K}$ for $24 \mathrm{~h}$. Subsequently, it was calcined at $1073 \mathrm{~K}$ for $6 \mathrm{~h}$. Post-calcination, the catalysts were ground and sieved to the size $<200 \mu \mathrm{m}$ for reaction studies.

\subsection{Characterization of The Catalysts}

The freshly-calcined catalysts were subjected to a series of characterization, viz. thermogravimetric analysis (TGA), x-ray fluorescence (XRF), x-ray diffraction (XRD), field emission scanning electron microscopy-energy dispersive $\mathrm{x}$-ray spectrometry (FESEM-EDS) and also specific surface area measurement by liquid $\mathrm{N}_{2}$ adsorption analysis. The XRD measurement employed radiation, $\lambda=1.5418$ $\AA$ at $30 \mathrm{kV}$ and $15 \mathrm{~mA}$, in $2 \theta$ from $10^{\circ}$ to $80^{\circ}$ with a step size of $0.02^{\circ}$ and step time of $1 \mathrm{~s}$. The crystalline size of the catalysts was determined from the Scherrer equation, $d=0.94 \lambda /(B d \cos \theta)$, where $d$ is the crystallite size, $\lambda$ is the wavelength of the radiation, $B d$ is the full-width at half maximum (FWHM) of the diffraction peak and $\theta$ is the half of the diffraction angle. The surface structure of the catalysts was captured by FESEM unit JOEL/JSM$7800 \mathrm{~F}$ model at $3 \mathrm{kV}$ with $\times 10,000$ magnification. Specific surface area was determined by BET model. The catalysts were degassed overnight at $573 \mathrm{~K}$ prior to specific surface area measurement at $77 \mathrm{~K}$. The cumulative pore volumes of the catalysts were determined by using Barrett-JoynerHalenda (BJH) analysis. The chemical composition of the catalysts was determined by both EDS and XRF. TGA analysis was performed to obtain the phase transformation of the catalyst in $\mathrm{N} 2$ atmosphere up to $1173 \mathrm{~K}$ employing the ramping rates of $10 \mathrm{~K} \mathrm{~min}^{-1}$.

\subsection{Catalyst Testing}

Figure 1 shows the experimental rig for the catalyst testing. The catalytic evaluation was carried out by placing $0.10 \mathrm{~g}$ of catalyst into the stainless steel 316 fixed-bed reactor (ID: $7 \mathrm{~mm}$ ) supported by two layers of quartz wool. The catalyst was reduced by $50 \% \mathrm{H}_{2} / \mathrm{Ar}$ gas $(50 \mathrm{ml} \mathrm{min}-1$ STP) for $2 \mathrm{~h}$ and held at $1073 \mathrm{~K}$. Glycerol was pumped into the reactor by HPLC pump while the flowrate of carrier gas (as diluent) was controlled using flowmeter controller. $\mathrm{CO}_{2}$ to glycerol ratio (CGR) was adjusted to determine the partial pressure of the reactants at constant weight-hourly space velocity (WHSV) of $7.2 \times 10^{4} \mathrm{ml} \mathrm{g}_{\text {cat }}{ }^{-1} \mathrm{~h}^{-1}$. The reaction temperature was set at $1023 \mathrm{~K}$ and ex- 
periments were repeated at temperatures between 973 and $923 \mathrm{~K}$ respectively. The composition of produced syngas was determined using online Agilent 3000 micro-gas chromatography (GC) with TCD column, Backflush Molecular Sieve 5A (10 m $\times 0.32 \mathrm{~mm})$ and Plot U column $(3 \mathrm{~m} \times 0.32 \mathrm{~mm})$ and Lancom III gas analyzer.

\subsection{Power Law Model}

Power law equation (cf. Equation (4)) was being used to approximate the kinetics of the glycerol dry reforming reactions and also its rate exponential.

$$
\mathrm{r}=\mathrm{kP} \mathrm{P}_{\mathrm{aly}}{ }^{\mathrm{a}} \mathrm{P}_{\mathrm{CO} 2}{ }^{\mathrm{b}}
$$

where $\mathrm{r}$ is rate of reaction ( $\mathrm{mol}$ gcat $^{-1} \mathrm{~s}^{-1}$ ), $\mathrm{k}$ is the rate constant, $P_{g l y}$ is the partial pressure of glycerol $(\mathrm{kPa}), P_{\mathrm{CO} 2}$ is the partial pressure of carbon dioxide $(\mathrm{kPa})$ while $\mathrm{a}$ and $\mathrm{b}$ are the order of reaction unique to the catalyst system. The reaction rate constant, $\mathrm{k}$ was expressed in Arrhenius form (cf. Equation (5)) to estimate the activation energy.

$$
\mathrm{k}=\mathrm{Ae}^{(-\mathrm{E} / \mathrm{RT})}
$$

where $\mathrm{A}$ is pre-exponential constant factor, $\mathrm{s}^{-1}$; Ea is activation energy, $\mathrm{kJ} \mathrm{mol}^{-1} ; \mathrm{T}$ is reaction temperature $(\mathrm{K})$ and $\mathrm{R}$ is the gas constant, $8.314 \mathrm{~J} \mathrm{~mol}^{-}$ ${ }^{1} \mathrm{~K}^{-1}$.

\section{Results and Discussion}

\subsection{Brunauer-Emmett-Teller (BET)}

Table 1 shows the density, BET surface area and cumulative pore volume of the catalysts with increasing Ni metal loading. Density measurement results generally agreed with Taylor [11] who reported that the density of cement clinker (CC) was between 3.15 to $3.2 \mathrm{~g} \mathrm{~cm}^{-3}$. BET surface area of the $100 \% \mathrm{CC}$ was relatively low $\left(0.55 \mathrm{~m}^{2} \mathrm{~g}^{-1}\right)$ in agree-

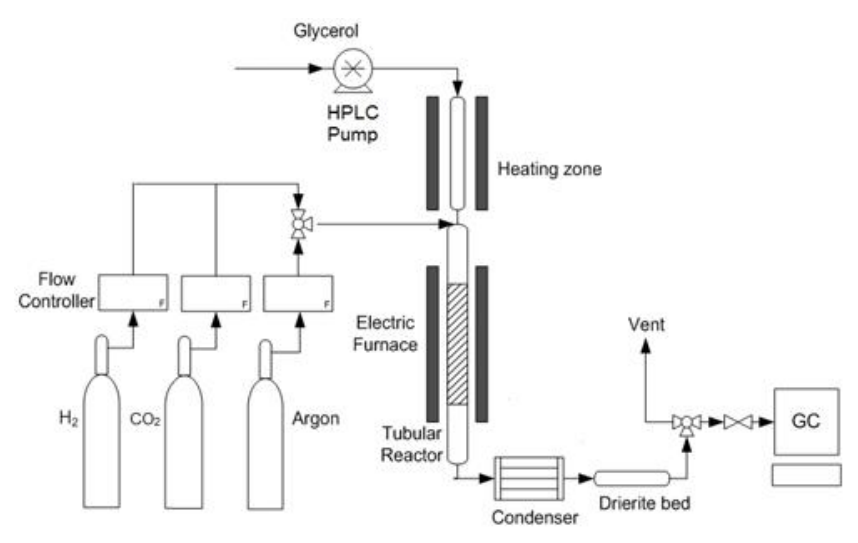

Figure 1. Experimental Setup ment with prior work by Chitra [12]. Low surface area of CC apparently related to the sintering effect of calcination at $1723 \mathrm{~K}$ in the cement kiln [13]. Significantly, Ni-doping has increased the BET specific surface area of the catalysts. This is a further testament of the successful deposition of $\mathrm{Ni}$ on the CC surface. The pore size of the $100 \%$ CC falls in the range of macroporous as observed from the physisorption isotherms (not shown). The isotherms displayed a shift towards mesoporous range with metal loadings. Therefore, this indicates the formation of new compound attributed to the alteration of the surface structure of the catalysts, which was further confirmed by XRF analysis tabulated in Table 2.

\subsection{X-ray Fluorescence (XRF)}

Table 2 shows that pure CC was in fact a mixture of oxide metals with $\mathrm{CaO}$ as the major ingredient at $61.98 \%$. This also corresponds to the earlier studies by Kurdowski [9] and Tsakiridris et al. [10]. Further inspection of Table 2 also revealed that the percentage of $\mathrm{CaO}$ and $\mathrm{SiO}_{2}$ in catalysts decreased from $61.98 \%$ to $38.66 \%$ and $17.21 \%$ to $6.77 \%$ respectively as $\mathrm{Ni}$ metal loading being increased. Indeed, the doping of $\mathrm{Ni}$ has increased the amount of $\mathrm{NiO}$ that originally also presents in the pure CC, contributed to a spike from $62 \mathrm{ppm}$ to $34.83 \%$. This observation was also confirmed by XRD analysis (cf. Figure 2).

\subsection{X-ray Diffraction (XRD)}

XRD analysis was carried out for both CC (Reference) and Ni-loaded catalysts. Diffractograms were shown in Figure 2. The main mineralogical phase presents in the CC was alite (tricalcium silicate, $\mathrm{Ca}_{3} \mathrm{SiO}_{5}$ ) in agreement with Shih et al. [14] judging from 11 peaks shown in Figure 2. Alite found in CC presents as monoclinic crystals due to the impurity contents [15], differed from pure alite that is triclinic. XRD also confirmed the presence of calcium aluminum iron manganese oxide $\left(\mathrm{Ca}_{2} \mathrm{Al}_{0} .67 \mathrm{Mn}_{0.33} \mathrm{FeO}_{5}\right)$ in $\mathrm{CC}$ with orthorhombic shape.

For 5\% Ni loading, clinker phase was essentially the same with presence of a substituted alite in nature named Hatrurite $\left(\mathrm{Ca}_{3} \mathrm{O}\left(\mathrm{SiO}_{4}\right)\right)$ [11]. Hatrurite has hexagonal crystals and X-ray lines were overlapped by those of larnite at $32.30^{\circ}, 32.60^{\circ}$, $34.45^{\circ}, 43.43^{\circ}, 46.91^{\circ}$ and $51.95^{\circ}$ in consensus with findings by Gross [15]. Ni was bonded with free $\mathrm{Mg}$ and $\mathrm{MnO}$ to form nickel magnesium manganese oxide $\left(\mathrm{Ni}_{0.9} \mathrm{MgO}_{-0.1}\right)_{6} \mathrm{MnO}_{8}$ determined at peaks $18.20^{\circ}, 43.43^{\circ}, 46.91^{\circ}$ and $60.08^{\circ}$. Moreover, calcium magnesium aluminum oxide $\left(\mathrm{Ca}_{54} \mathrm{MgAl}_{2} \mathrm{Si}_{16} \mathrm{O}_{90}\right)$ species presence as orthorhombic $\left(2 \theta=29.53^{\circ}\right.$, 
$32.30^{\circ}, 32.60^{\circ}, 34.45^{\circ}, 41.31^{\circ}, 51.95^{\circ}, 56.54^{\circ}$ and $\left.62.35^{\circ}\right)$ as evinced in 5\% Ni-95\% CC catalyst. Nonetheless, the peak intensities decreased with $\mathrm{Ni}$ content as compared with XRD patterns of $100 \%$ CC. This corroborated with Shui et al. [16] who reported that alite peaks ceases in fly ash and slowly replaced by $\mathrm{Ca}_{54} \mathrm{MgAl}_{2} \mathrm{Si}_{16} \mathrm{O}_{90}$ (flue gas desulfurater) after reactions. The crystal, $\mathrm{Ca}_{54} \mathrm{MgAl}_{2} \mathrm{Si}_{16} \mathrm{O}_{90}$ which acts as flue gas desulfurater was estimated to reduce the poisoning effect of catalyst during the reactions testing and enhance the catalytic performance.

For $10 \% \mathrm{Ni}$ loading, calcium nickel catenadisilicate (Nickeldiopside, $\mathrm{CaNi}\left(\mathrm{Si}_{2} \mathrm{O}_{6}\right)$ ) and calcium nickel silicate $\left(\mathrm{CaNiSi}_{4} \mathrm{O}_{10}\right)$ was found in monoclinic and tetragonal system respectively. The presence of $\mathrm{CaNi}\left(\mathrm{Si}_{2} \mathrm{O}_{6}\right)$ and $\mathrm{CaNiSi}_{4} \mathrm{O}_{10}$ were due to the existence of $\mathrm{Ni}, \mathrm{Ca}_{3} \mathrm{SiO}_{5}$, silicon dioxide $\left(\mathrm{SiO}_{2}\right)$ and $\mathrm{NiO}$, which underwent reactions in Eqs. (6) and (7) during the calcination stage as mentioned by Masse [17].

$$
\begin{aligned}
& \mathrm{Ca}_{3} \mathrm{SiO}_{5}+5 \mathrm{SiO}_{2}+3 \mathrm{NiO} \rightarrow 3 \mathrm{CaNiSi}_{2} \mathrm{O}_{6} \\
& \mathrm{Ca}_{3} \mathrm{SiO}_{5}+11 \mathrm{SiO}_{2}+3 \mathrm{NiO} \rightarrow 3 \mathrm{CaNiSi}_{4} \mathrm{O}_{10}
\end{aligned}
$$

For Ni loading more than $10 \%$, the promotion of alite to larnite ( $B$-belite, $\mathrm{Ca}_{2} \mathrm{SiO}_{4}$ ) was being observed. Similar result was reported before by Sinyoung et al. [18]. They have investigated the effect of chromium metal loading in CC. Increasing peak intensities across $2 \theta$ of $37^{\circ}$ and $43^{\circ}$ signified the in- crement of crystalline size of larnite with $\mathrm{Ni}$ content.

In contrast, with $\mathrm{Ni}$ loading of up to $15 \%$, Bunsenite $(\mathrm{NiO})$, in cubic system and $\mathrm{Ca}_{2} \mathrm{SiO}_{4}$, in monoclinic were found to be the main components. The XRD results detected the crystalline in the form of $\mathrm{Ca}_{2} \mathrm{SiO}_{4}$ instead of Shannonite ( $\gamma$-belite) which can be attributed to the presence of impurity ions and also slow rate of cooling after the calcination [10]. The results demonstrated that the $\mathrm{Ni}$ metal has inhibited the transformation of $\mathrm{Ca}_{2} \mathrm{SiO}_{4}$ back to $\mathrm{Ca}_{3} \mathrm{SiO}_{5}$ and there was no alite corresponding to results by Sinyoung et al. [18]. High Ni loading $>10 \%$ seems to assist the $\mathrm{Ca}_{3} \mathrm{SiO}_{5}$ polymorph to decompose and transform to $\mathrm{Ca}_{2} \mathrm{SiO}_{4}$, and $\mathrm{NiO}$ species as illustrated in Figure 2, as also obtained by Shih et al. [14].

With the loading of Ni metals, a slight shift of $2 \theta$ to a lower degree value can be observed from a closer scrutiny towards peaks occurs at $32^{\circ}$ and $34^{\circ}$ in Figure 3. Significant reduction of peaks intensities between $32-36^{\circ}$ and left shifting effects indicates structural transformation due to Ni loading. Subsequently, the peak intensities especially the larnite compounds at peak $43^{\circ}$ increases indicating an increase of crystalline size (cf. Figure 4 and Table 3). The XRD results (shows the occurrence of Bunsenite, $\mathrm{NiO}$ ) are comparable with the results in $\mathrm{XRF}$ indicating a decreasing amount of $\mathrm{CaO}$ and $\mathrm{SiO}_{2}$ for $\mathrm{NiO}$ formation.

Table 1. Composition, BET specific surface area and density of the catalysts

\begin{tabular}{ccccc}
\hline \multicolumn{2}{c}{ Composition (wt \%) } & $\begin{array}{c}\text { BET } \\
\text { specific surface area } \\
\left(\mathrm{m}^{2} \mathrm{~g}^{-1}\right)\end{array}$ & $\begin{array}{c}\text { Density } \\
\left(\mathrm{g} \mathrm{cm}^{-3}\right)\end{array}$ & $\begin{array}{c}\text { Cumulative Pore } \\
\text { Volume } \\
\left(\mathrm{cm}^{3} \mathrm{~g}^{-1}\right)\end{array}$ \\
\hline $\mathrm{Ni}$ & $\mathrm{CC}$ & 0.55 & 2.99 & 0.0000 \\
5 & 100 & 7.73 & 3.03 & 0.0022 \\
10 & 95 & 15.81 & 3.12 & 0.0053 \\
15 & 90 & 17.30 & 3.12 & 0.0054 \\
20 & 85 & 17.83 & 3.22 & 0.0057 \\
\hline
\end{tabular}

Table 2. XRF results of the catalysts

\begin{tabular}{cccccc}
\hline Catalysts & $\mathbf{C a O}$ & $\mathrm{NiO}$ & $\mathbf{S i O}_{2}$ & $\mathrm{Al}_{2} \mathbf{O}_{3}$ & $\mathrm{Fe}_{2} \mathbf{O}_{3}$ \\
\hline $100 \% \mathrm{CC}$ & 61.98 & $62^{*}$ & 17.21 & 3.90 & 3.53 \\
$5 \% \mathrm{Ni}-95 \% \mathrm{CC}$ & 53.05 & 18.67 & 11.49 & 2.66 & 2.64 \\
$10 \% \mathrm{Ni}-90 \% \mathrm{CC}$ & 57.02 & 14.14 & 8.44 & 3.07 & 3.16 \\
$15 \% \mathrm{Ni}-85 \% \mathrm{CC}$ & 44.11 & 27.63 & 9.28 & 1.75 & 2.38 \\
$20 \% \mathrm{Ni}-80 \% \mathrm{CC}$ & 38.66 & 34.83 & 6.77 & 1.36 & 2.07 \\
\hline
\end{tabular}

The data presented was in wt \% except for * in ppm. 


\subsection{FESEM Studies}

The surface morphology obtained by FESEM imaging shows that the surface of pure CC (cf. Figure 5(a)) was very smooth and appeared nonporous. Interestingly, at the loading of $15 \% \mathrm{Ni}$ (representative sample), the surface of the resulting catalyst has become rougher and bulkier with creation of more finely dispersed crystallites (cf. Fig. 5(b)). This may have explained the higher BET surface area obtained (cf. Table 1).

\subsection{TGA- Calcination Studies}

Calcination profiles of both $15 \%$ and $20 \% \mathrm{Ni}$ doping in $\mathrm{N}_{2}$ atmosphere was plotted as in Figure 6. Calcination profiles obtained from thermogravimetric analysis (TGA) shown in Figure 6 for pure $100 \%$ CC shows a thermal stability with no obvious decomposition. Calcination profiles for $15 \% \mathrm{Ni}-85 \%$ $\mathrm{CC}$ and $20 \% \mathrm{Ni}-80 \% \mathrm{CC}$ catalysts (as representative samples) showed approximately similar trend of decomposition in $\mathrm{N}_{2}$ atmosphere. Peaks formation before $500 \mathrm{~K}$ were probably due to the water vapour entrainment in the catalysts.

For both $15 \%$ and $20 \% \mathrm{Ni}$ catalysts in Figure 6, there were formations of two peaks around 504 to $620 \mathrm{~K}$ and 620 to $794 \mathrm{~K}$ (with a shoulder peak around $673 \mathrm{~K}$ ) respectively. The peaks for $20 \% \mathrm{Ni}$

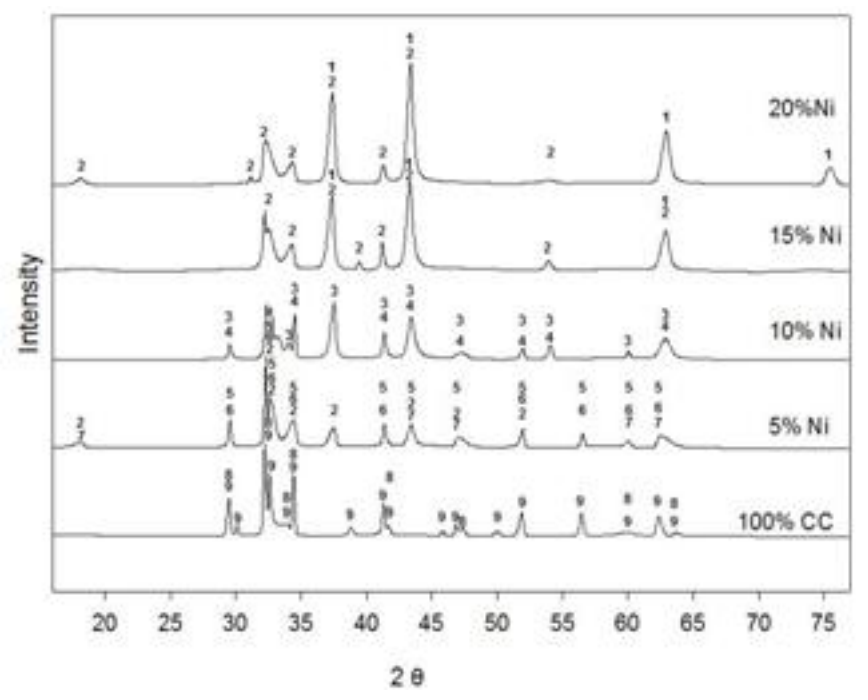

Figure 2. XRD results of catalysts. (1: Bunsenite, $\mathrm{NiO}$; 2: Larnite, $\mathrm{Ca}_{2} \mathrm{SiO}_{4}$; 3: Calcium Nickel Catena Silicate, $\mathrm{CaNiSi}_{2} \mathrm{O}_{6}$; 4: Calcium Nickel Silicate, $\mathrm{CaNiSi}_{4} \mathrm{O}_{10}$; 5: Hatrurite, $\mathrm{Ca}_{3} \mathrm{O}\left(\mathrm{SiO}_{4}\right) ; 6$ : Calcium Magnesium Aluminum Oxide Silicate, $\mathrm{Ca}_{54} \mathrm{MgAl}_{2}$. $\mathrm{Si}_{16} \mathrm{O}_{90} ; 7$ : Nickel Magnesium Manganese Oxide, $\left(\mathrm{Ni}_{0.9} \mathrm{MgO}_{-0.1}\right)_{6} \mathrm{MnO}_{8}$; 8: Calcium Aluminum Iron Manganese Oxide, $\mathrm{Ca}_{2} \mathrm{Al}_{0.67} \mathrm{Mn}_{0.33} \mathrm{FeO}_{5}$; 9: Alite, $\mathrm{Ca}_{3} \mathrm{SiO}_{5}$ ) catalyst were shifted to the right as compared to $15 \% \mathrm{Ni}$ catalyst. The first peak (504 to $620 \mathrm{~K}$ ) was due to the transformation of $\mathrm{Ni}_{3}\left(\mathrm{NO}_{3}\right)_{2}(\mathrm{OH})_{4}$ to $\mathrm{NiO}$ in consensus with Estellé et al. [19]. It was also proven by the formation of highest peak that occurs at $580 \mathrm{~K}$ (green line) which indicates the full decomposition of nitrate in of nickel (II) nitrate hexahydrate $\left(\mathrm{Ni}\left(\mathrm{NO}_{3}\right)_{2} \cdot 6 \mathrm{H}_{2} \mathrm{O}\right)$ (cf. Figure 6). $\mathrm{Ni}_{3}\left(\mathrm{NO}_{3}\right)_{2}(\mathrm{OH})_{4}$ species was most likely obtained from the subsequent decomposition of $\mathrm{Ni}\left(\mathrm{NO}_{3}\right)_{2} .6 \mathrm{H}_{2} \mathrm{O}$ during the drying of wetimpregnated catalyst at $403 \mathrm{~K}$ whilst second peak formed ( 620 to $794 \mathrm{~K}$ ) was an indicative of $\mathrm{NiO}$ formation due to the total metal precursor (nickel (II) nitrate hexahydrate) decomposition in agreement with Loaiza-Gil et al. [20]. The calcination profiles corroborated with the XRD patterns which showed the presence of $\mathrm{NiO}$. The formation of the shoulder peak at $673 \mathrm{~K}$ indicates the continuous thermal decomposition of a complex mixture of hydrated sili-

Table 3. Crystalline size of larnite, $\mathrm{Ca}_{2} \mathrm{SiO}_{4}$ at $2 \theta$ around $43^{\circ}$ with $\mathrm{Ni}$ content

\begin{tabular}{cccc}
\hline Ni loading & $\mathbf{5 \%}$ & $\mathbf{1 5 \%}$ & $\mathbf{2 0 \%}$ \\
\hline 20, degree & 43.43 & 43.29 & 43.36 \\
FWHM $(\beta)$, degree & 0.52 & 0.50 & 0.48 \\
Crystalline Size (d), ̊ & 172 & 179 & 186 \\
\hline
\end{tabular}

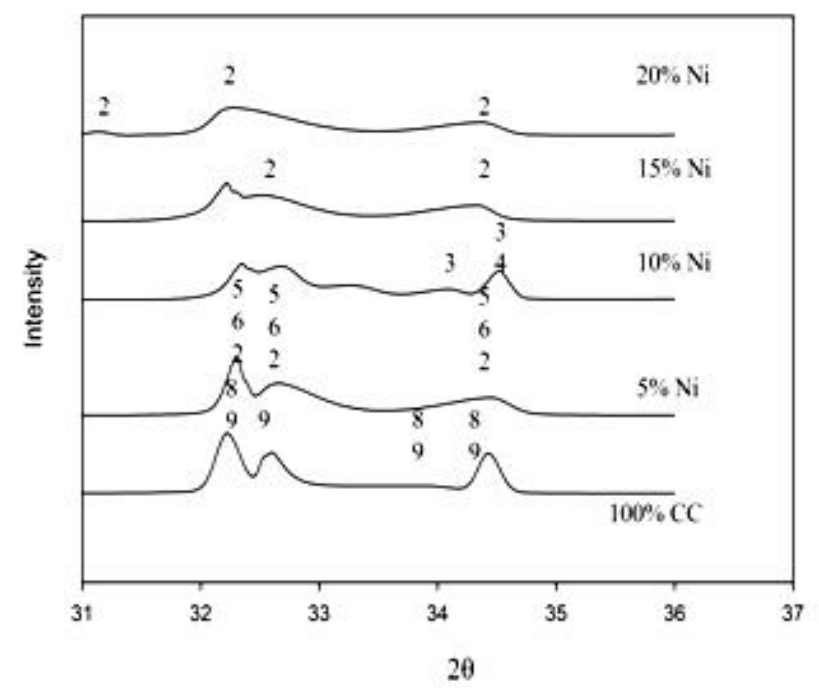

Figure 3. A closer scrutiny to compounds at $2 \theta$ of $31^{\circ}$ to $36^{\circ}$ (2: Larnite, $\mathrm{Ca}_{2} \mathrm{SiO}_{4}$; 3: Calcium Nickel Catena Silicate, $\mathrm{CaNiSi}_{2} \mathrm{O}_{6}$; 4: Calcium Nickel Silicate, $\mathrm{CaNiSi}_{4} \mathrm{O}_{10}$; 5: Hatrurite, $\mathrm{Ca}_{3} \mathrm{O}\left(\mathrm{SiO}_{4}\right)$; 6: Calcium Magnesium Aluminum Oxide Silicate, $\mathrm{Ca}_{54} \mathrm{MgAl}_{2} \mathrm{Si}_{16} \mathrm{O}_{90}$; 8: Calcium Aluminum Iron Manganese Oxide, $\mathrm{Ca}_{2} \mathrm{Al}_{0.67} \mathrm{Mn}_{0.33} \mathrm{FeO}_{5} ; \quad$ 9: Alite, $\left.\mathrm{Ca}_{3} \mathrm{SiO}_{5}\right)$ 
cate and aluminate-type compounds as described by Gabrovšek et al. [21]. The decomposition of silicate described the formation of $\mathrm{Ca}_{2} \mathrm{SiO}_{4}$ crystalline present in $15 \% \mathrm{Ni}-85 \% \mathrm{CC}$ and $20 \% \mathrm{Ni}-80 \% \mathrm{CC}$ catalysts.

\subsection{Reaction Studies}

Figure 7 shows the hydrogen product ratio profiles for glycerol dry reforming carried out at 1023 $\mathrm{K}$ over $15 \% \mathrm{Ni}-85 \% \mathrm{CC}$ catalyst. Overall, $\mathrm{H}_{2}, \mathrm{CO}$ and $\mathrm{CH}_{4}$ were produced. Blank tests using the same feed with either an empty reactor or $100 \%$ $\mathrm{CC}$ bed yielded negligible glycerol conversion. This suggests that neither homogeneous gas phase glycerol dry reforming nor reaction over sites on the support occurred at detectable rates. The slight de-

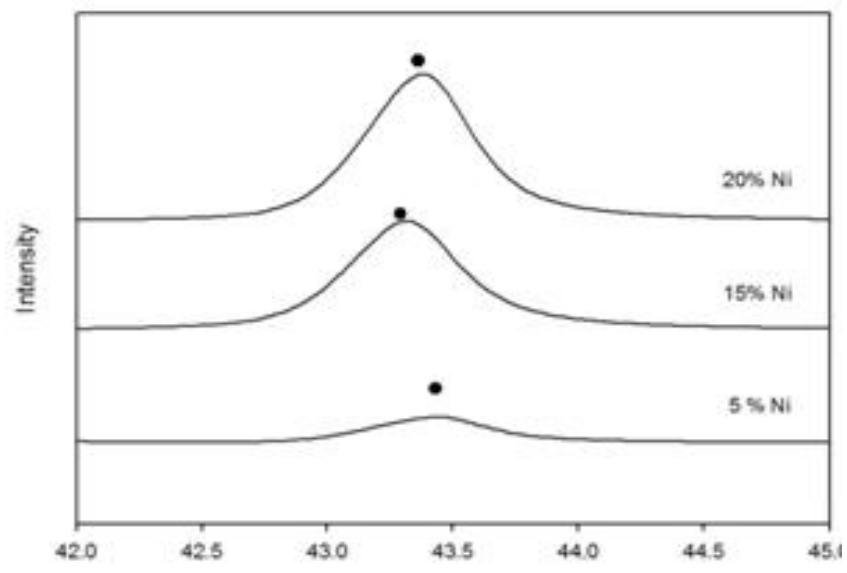

Figure 4. Peaks intensities of larnite, $\mathrm{Ca}_{2} \mathrm{SiO}_{4}$ at $2 \theta$ around $43^{\circ}$ with $\mathrm{Ni}$ content

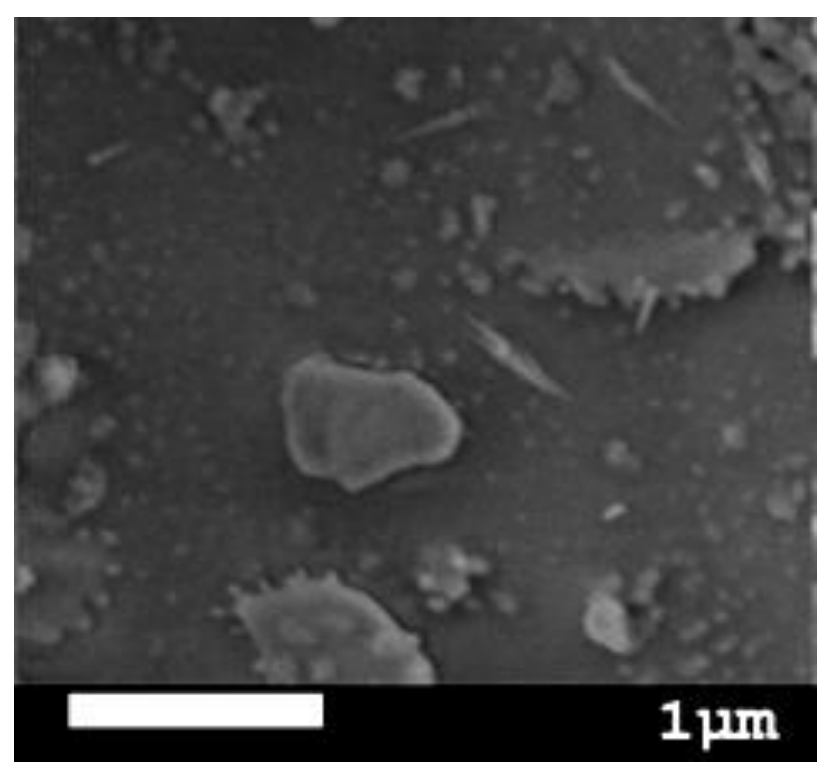

crease of $\mathrm{H}_{2}$ : $\mathrm{CO}$ ratio with $\mathrm{P}_{\mathrm{CO} 2}$ is most likely an attribute of the reverse-water-gas-shift reaction. Nonetheless, the $\mathrm{H}_{2}$ : $\mathrm{CO}$ ratio remained $>1.0$. In addition, the formation behaviour of both $\mathrm{CH}_{4}$ and $\mathrm{CO}$ also forms the focal point of the current study as these two species are well-known carbon precursors via methane cracking and Boudouard reaction respectively. Hence, transient product ratio profiles of $\mathrm{CO}: \mathrm{CH}_{4}$ were plotted and shown in Figure 8 for $15 \% \mathrm{Ni}-85 \% \mathrm{CC}$ catalyst at different partial
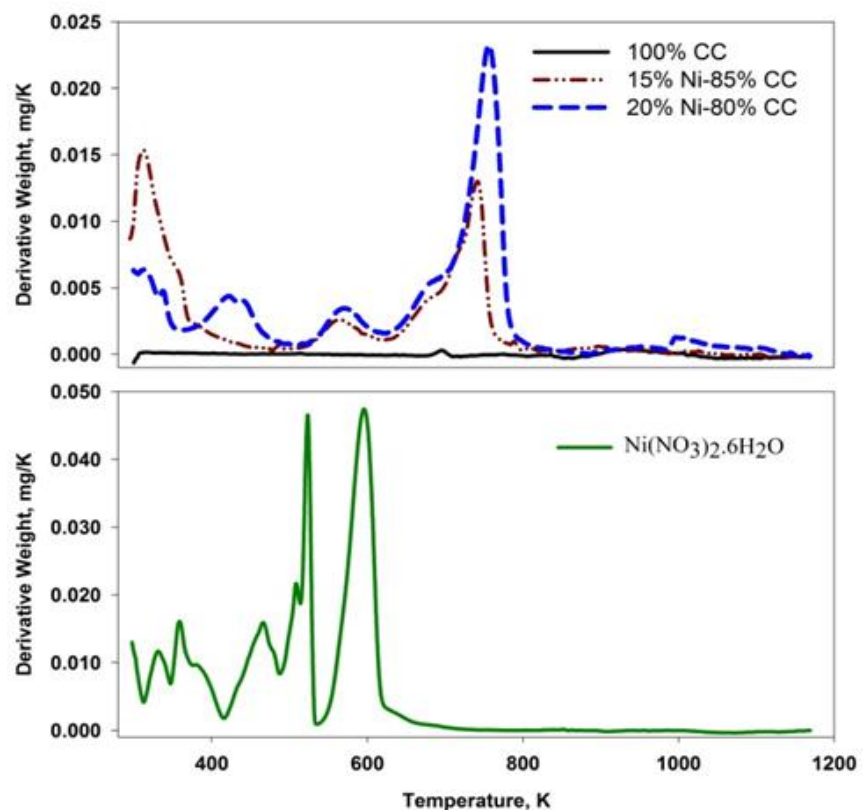

Figure 6. TGA analysis of catalysts and $\mathrm{Ni}\left(\mathrm{NO}_{3}\right)_{2} \cdot 6 \mathrm{H}_{2} \mathrm{O}$ at $10 \mathrm{~K} \mathrm{~min}-1$ ramping rate in $\mathrm{N}_{2}$ atmosphere

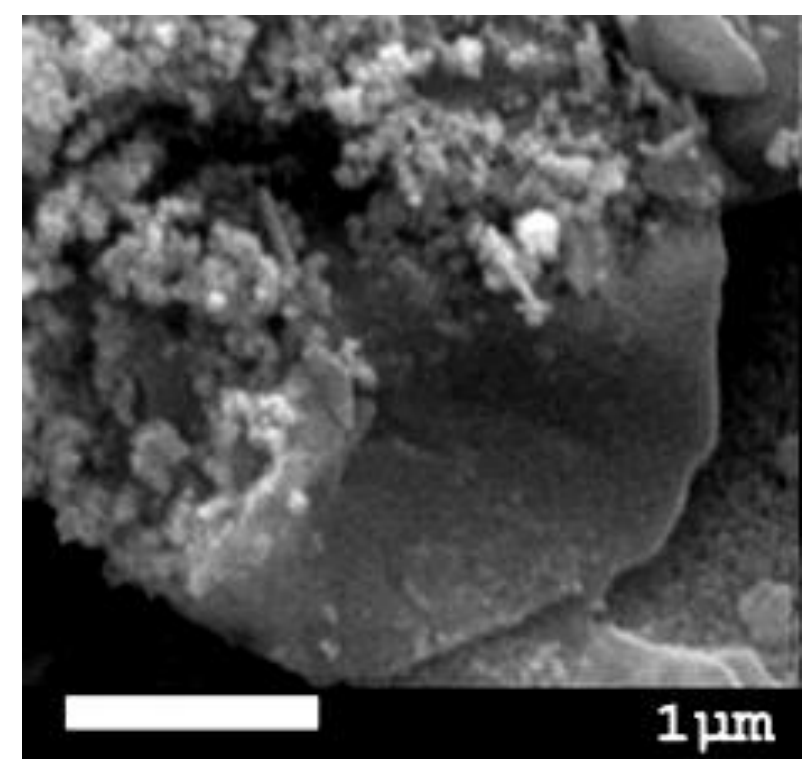

Figure 5. FESEM image, (a) fresh CC support and (b) fresh 15\% Ni-85\% CC 
pressure of carbon dioxide, $P_{\mathrm{CO} 2}$. For $P_{\mathrm{CO} 2}$ at $42 \mathrm{kPa}$ (CGR 3:1), the $\mathrm{CO}: \mathrm{CH}_{4}$ ratio increased in the first $30 \mathrm{~min}$ of reaction time and thereafter gradually dropped. For $P_{\mathrm{CO} 2}$ at $14.0 \mathrm{kPa}$ (CGR 1:1), the $\mathrm{CO}: \mathrm{CH}_{4}$ ratio gradually increases up to 6.5 , an indication of the decrease in $\mathrm{CH}_{4}$. Indeed, higher $\mathrm{CGR}$ and higher temperature favour the formation of $\mathrm{CO}$. However, Figure 8 depicts that the $\mathrm{CH}_{4}$ formation was also increased with higher CGR. This could be explained by Equation (8), where the excess $\mathrm{CO}_{2}$ has reacted with $\mathrm{H}_{2}$ to form methane, $\mathrm{CH}_{4}$. This was further proven by the methane production rate illustrated in Figure 9. The average methane production rate for $15 \% \mathrm{Ni}-85 \%$ CC catalysts at $P_{\mathrm{CO} 2}, 14.0 \mathrm{kPa}$ (CGR 1:1) was $1.46 \mathrm{E}-5 \mathrm{~mol}$

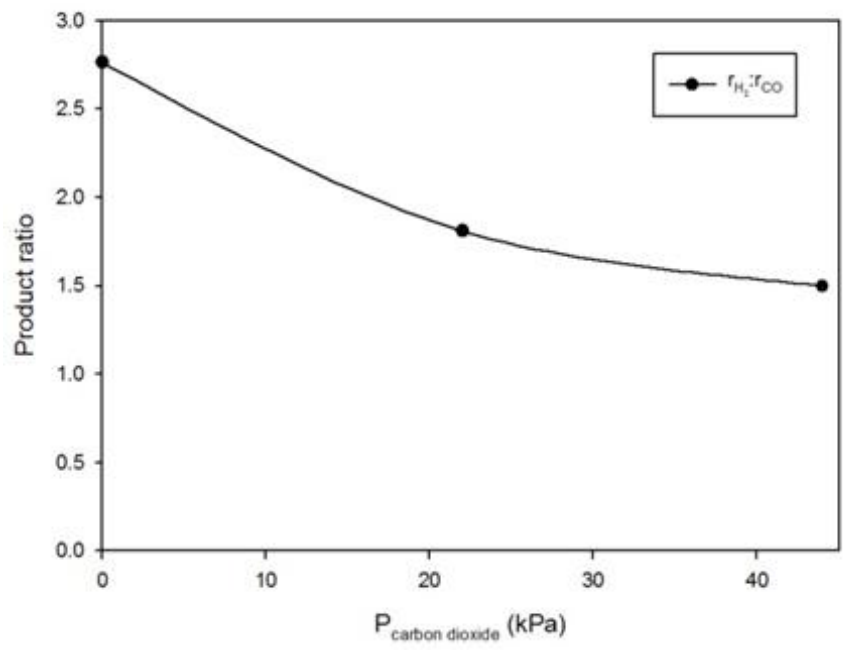

Figure 7. $\mathrm{H}_{2}: \mathrm{CO}$ product ratio at $1023 \mathrm{~K}$

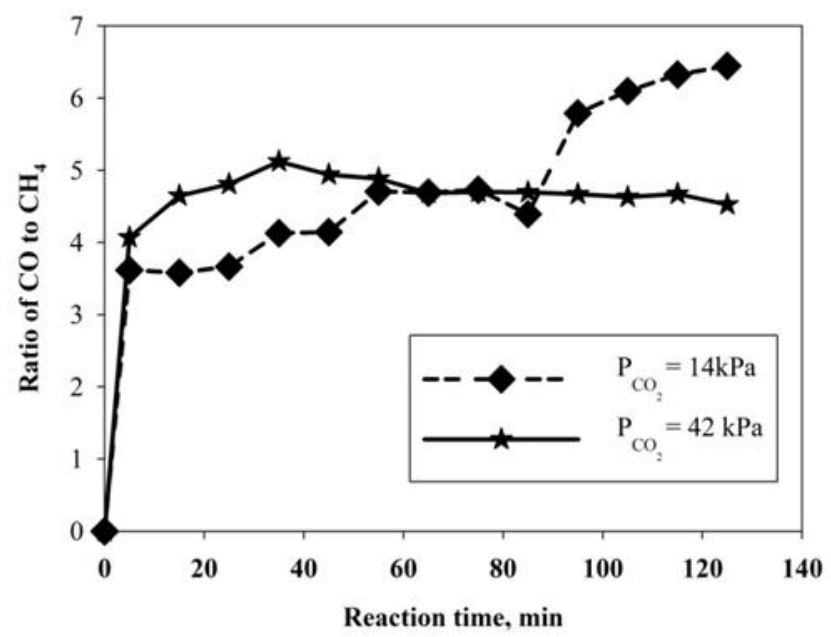

Figure 8. Typical transient $\mathrm{CO}: \mathrm{CH}_{4}$ of $15 \% \mathrm{Ni}$ $85 \% \mathrm{CC}$ catalysts for $\mathrm{Pco}_{2}=14 \mathrm{kPa}$ and $\mathrm{Pco}_{2}=42$ $\mathrm{kPa}$ at $1023 \mathrm{~K}$ $\mathrm{g}_{\text {cat }^{-1}} \mathrm{~s}^{-1}$ while for the $P_{\mathrm{CO} 2}$ of $42.0 \mathrm{kPa}$, with CGR $3: 1$, the average methane production rate was $4.9 \mathrm{E}-5 \mathrm{~mol} \mathrm{gat}^{-1} \mathrm{~s}^{-1}$.

$$
\mathrm{CO}_{2}+4 \mathrm{H}_{2} \leftrightarrow \mathrm{CH}_{4}+2 \mathrm{H}_{2} \mathrm{O}
$$

Interestingly, excess $\mathrm{CO}_{2}$ (culminate in CGR 3:1) did not promote Boudouard reaction (cf. Equation (9) to form $\mathrm{CO}$ as the $\mathrm{CO}$ to $\mathrm{CH}_{4}$ ratio remained constant at circa 4.6 for CGR 3:1 $\left(P_{\mathrm{CO} 2}=\right.$ $42.0 \mathrm{kPa}$ ). Most likely, reaction as in Eq. (10) also has taken place.

$$
\begin{aligned}
& 2 \mathrm{CO} \leftrightarrow \mathrm{CO}_{2}+\mathrm{C} \\
& \mathrm{CO}_{2}+2 \mathrm{H}_{2} \leftrightarrow \mathrm{C}+2 \mathrm{H}_{2} \mathrm{O}
\end{aligned}
$$

Therefore, $P_{\mathrm{CO} 2}$ needed to be regulated to obtain the maximum conversion of glycerol with the least carbon deposition.

\section{Conclusion}

Cement clinker catalyst with $\mathrm{Ni}$ dopants could be a potential catalyst for the purpose of producing syngas from glycerol dry reforming. Physicochemical characterization has revealed that cement clinker was a complex mixture of oxide compounds with $\mathrm{CaO}$ and $\mathrm{SiO}$ accounted for more than half (62\% and $17 \%$ respectively). Although cement clinker was non-porous, addition of $\mathrm{Ni}$ has improved significantly the BET surface area with at least 32 -folds increment. XRD examination showed formation of complex oxide phases depending on the Ni loading. Interestingly, glycerol dry reforming reaction yield $\mathrm{H}_{2}: \mathrm{CO}<2.0$, suitable for

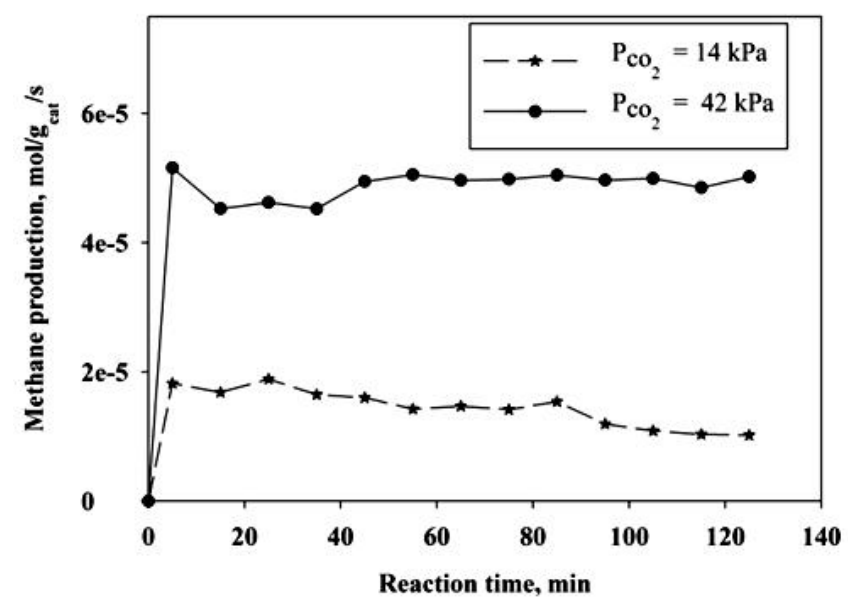

Figure 9. Methane production rate of $15 \% \mathrm{Ni}$ $85 \% \mathrm{CC}$ catalysts at $\mathrm{P}_{\mathrm{CO} 2}=14 \mathrm{kPa}$ and $\mathrm{P}_{\mathrm{CO} 2}=42$ $\mathrm{kPa}$ at $1023 \mathrm{~K}$ 
Fischer-Tropsch synthesis. Nonetheless, the sidereactions such as methanation and hydrogenation of $\mathrm{CO}_{2}$ have majorly affected the amount of syngas produced.

\section{References}

[1] Rossi, D.M., Costa, J. B., Souza, E.A., Peralba, M.C.R., Samios, D., Ayub, M.A.Z. (2011). Comparison of Different Pretreatment Methods for Hydrogen Production using Environmental Microbial Consortia on Residual Glycerol from Biodiesel. International Journal of Hydrogen Energy 36: 4814-4819.

[2] Wang, X., Li, M., Wang, M., Wang, H., Li, S., Wang, S., Ma, X. (2009). Thermodynamic Analysis of Glycerol Dry Reforming of Hydrogen and Synthesis Gas Production. Fuel 88: 2148-2153.

[3] Dantas, S.C., Escritori, J.C., Soeres, R.R., Hori, C.E. (2010). Effect of Different Promoters on $\mathrm{Ni} / \mathrm{CeZrO}_{2}$ Catalyst for Autothermal Reforming and Partial Oxidation of Methane. Chemical Engineering Journal, 156: 380-387.

[4] Bermúdez, J.M., Fidalgo, B., Arenillas, A., Menéndez, J.A. (2012). $\mathrm{CO}_{2}$ Reforming of Coke Oven Gas over A Ni/ $/ \mathrm{Al}_{2} \mathrm{O}_{3}$ Catalyst to Produce Syngas for Methanol Synthesis. Fuel 94: 197-203.

[5] Zhang, Y., Zhang, G., Zhang, B., Guo, F., Sun, Y. (2011). Effects of Pressure on $\mathrm{CO}_{2}$ Reforming of $\mathrm{CH}_{4}$ over Carbonaceous Catalyst. Chemical Engineering Journal 173: 592-597.

[6] Bellido, J.D.A., Souza, J.E.D., M'Peko, J.C., Assaf. E.M. (2009). Effect of Adding $\mathrm{CaO}$ to $\mathrm{ZrO}_{2}$-Support on Nickel Catalyst Activity in Dry Reforming of Methane. Applied Catalysis A: General 358: 215-223.

[7] Al-fatish, A.S.A., Ibrahim, A.A., Fakeeha, A.H., Soliman, M.A., Siddiqui, M.R.H., Abasaeed, A.E. (2009). Coke Formation during $\mathrm{CO}_{2}$ Reforming of $\mathrm{CH}_{4}$ over Alumina-supported Nickel Catalysts. Applied Catalysis A: General 364: 150-155.

[8] Ruckenstein, E., Hu, Y.H. (1995). Carbon Dioxide Reforming of Methane over Nickel/Alkaline Earth Metal Oxide Catalysts. Applied Catalysis A: General 133: 149-161.

[9] Kurdowski, W. (2002). Role of Delayed Release of Sulphates from Clinker in DEF. Cement and Concrete Research 32: 401-407.

[10] Tsakiridis, P.E., Agatzini-Leonardaou, S., Oustadakis, P., Katsioti, M., Mauridou, E. (2005). Ex- amination of The Jarosite-Alunite Precipitate Addition in The Raw Meal for The Production of Portland Cement Clinker. Cement and Concrete Research 35: 2066-2073.

[11] Taylor, H.F.W (1997). Cement Chemistry, London: Thomas Telford Publishing. 89.

[12] Chitra, C. (2011). Biodiesel Production from Rubber Seed Oil using Activated Clinker as Catalyst. Bachelor Degree Thesis, Universiti Malaysia Pahang.

[13] Li, H., Agrawal, D.K., Cheng, J., Silsbee, M.R. (1999). Formation and Hydration of $\mathrm{C}_{3} \mathrm{~S}$ Prepared by Microwave and Conventional Sintering. Cement and Concrete Research 29: 1611-1617.

[14] Shih, P., Chang, J., Lu, H., Chiang, L. (2005). Reuse of Heavy Metal-containing Sludges in Cement Production. Cement and Concrete Research 35: 2110-2115.

[15] Gross, S. (1997). The Mineralogy of The Hatrurim Formation, Israel. Geol. Survey Israel Bull., 70: 80.

[16] Shui, A., Gong, H., Zeng, L., Wang, H., Liu, P., Cheng, X. (2008). Preparation of Flue Gas Desulfurater by Mechanochemical Effect. Bulletin of The Chinese Ceramic Society 27(1): 1001-1625.

[17] Masse, S., Boch, P., Vaissière, N. (1999). Trapping of Nickel and Cobalt in $\mathrm{CaNiSi}_{2} \mathrm{O}_{6}$ and $\mathrm{CaCoSi}_{2} \mathrm{O}_{6}$ Diopside-Like Phases in Heat-Treated Cement. Journal of European Ceramic Society 19: 93-98.

[18] Sinyoung, S., Songsiriritthigul, P., Suwimol, A., Kajitvichyanukul, P. (2011). Chromium Behavior during Cement-Production Processes: A Clinkerization, Hydration, and Leaching study. Journal of Hazardous Materials 191: 296-305.

[19] Estellé, J., Salagre, P., Cesteros, Y., Serra, M., Medina, F., Sueiras, J.E. (2003). Comparative Study of The Morphology and Surface Properties of Nickel Oxide Prepared from Different Precursors. Solid State Ionics 156: 233-243.

[20] Loaiza-Gil, A., Villarroel, M., Balbuena, J.F., Lacruz, M.A., Gonzalez-Cortés. (2008). Thermal Decomposition Study of Silica-supported Nickel Catalyst Synthesized by The Ammonia Method. Journal of Molecular Catalysis A: Chemical 281: 207-213.

[21] Gabrovšek, R., Vuk, T., Kaučič, V. (2006). Evaluation of the Hydration of Portland Cement Containing Various Carbonates by Means of Thermal Analysis. Acta Chim. Slov. 53: 159-165. 